\title{
Author Correction: Nonlinearity of root trait relationships and the root economics spectrum
}

Deliang Kong (D), Junjian Wang, Huifang Wu, Oscar J. Valverde-Barrantes, Ruili Wang, Hui Zeng, Paul Kardol (1D, Haiyan Zhang \& Yulong Feng (D)

Correction to: Nature Communications https://doi.org/10.1038/s41467-019-10245-6, published online 17 May 2019.

In the Acknowledgements section of this article, the grant number relating to the National Natural Science Foundation of China given for Deliang Kong was incorrectly given as 31870552 and should have been 31870522 . The original article has been corrected.

Published online: 08 February 2022

\begin{abstract}
(c) Open Access This article is licensed under a Creative Commons Attribution 4.0 International License, which permits use, sharing, adaptation, distribution and reproduction in any medium or format, as long as you give appropriate credit to the original author(s) and the source, provide a link to the Creative Commons license, and indicate if changes were made. The images or other third party material in this article are included in the article's Creative Commons license, unless indicated otherwise in a credit line to the material. If material is not included in the article's Creative Commons license and your intended use is not permitted by statutory regulation or exceeds the permitted use, you will need to obtain permission directly from the copyright holder. To view a copy of this license, visit http://creativecommons.org/licenses/by/4.0/.
\end{abstract}

(c) The Author(s) 2022 